\title{
Role of Resveratrol on the Effect of Resistin in Rabbit Corpus Cavernosum
}

\section{Resistinin Tavşan Korpus Kavernosumundaki Etkisi Üzerine Resveratrolün Rolü}

\author{
(1) Türkan Güngör1', (1) Selin Acar1, (1) Erkan Kahraman22, (1) 0zan Bozkurt33, (1) Nergiz Durmuş̧4 \\ ${ }^{1}$ Dokuz Eylül University Faculty of Medicine, Department of Health Sciences, İzmir, Turkiye \\ ${ }^{2}$ Ege University Faculty of Medicine, Atatürk Vocational School of Health Services, İmir, Turkiye \\ ${ }^{3}$ Dokuz Eylül University Faculty of Medicine, Department of Urology, Izmir, Turkiye \\ ${ }^{4}$ Dokuz Eylül University Faculty of Medicine, Department of Pharmacology, Izmir, Turkiye
}

\section{What's known on the subject? and What does the study add?}

Resistin has been shown to disrupt endothelium-dependent relaxation responses in in vitro experimental studies in vessels via increasing reactive oxygen species, decreasing nitric oxide activity and increasing synthesis of endothelin 1 . Resveratrol has been shown to prevent and restore vascular and penile endothelial dysfunction. Resveratrol has also been reported to reduce elevated resistin levels in the white adipocytes. Four hours incubation period of resistin did not impair penile endothelial functions but tend to increase nicotinamide adenine dinucleotide phosphate oxidase activity. Resveratrol administration caused a significant decrease in nicotinamide adenine dinucleotide phosphate oxidase activity in the penile tissue.

\begin{abstract}
Objective: Resistin is an important factor in the pathogenesis of obesity-induced insulin resistance and endothelial dysfunction-mediated cardiovascular system diseases. Endothelial dysfunction is one of the most important causes of erectile dysfunction. Polyphenol resveratrol has several pharmacological functions, such as preventing endothelial dysfunction and inducing endothelium-dependent vascular relaxation via redox regulation and nitric oxide production. The present study tested the hypothesis that resveratrol restores endothelium-mediated responses that are disrupted by resistin.

Materials and Methods: After a $24 \mathrm{~h}$ incubation period of tissues with resistin, endothelium-dependent and independent relaxation responses and nicotinamide adenine dinucleotide phosphate (NADPH) oxidase level were evaluated in the presence and absence of resveratrol in rabbit corpus cavernosum (CC).

Results: Resistin caused no impairment in the endothelium-dependent and -independent relaxation responses. In the presence of resistin, NADPH oxidase levels increased by $28 \%$ in the CC tissues. However, the difference was not statistically significant. Resveratrol administration caused a significant decrease in NADPH oxidase activity in the resistin-treated group compared with the resistin-alone group.

Conclusion: Resistin caused no changes in the functional responses of CC and NADPH oxidase activity, but resveratrol incubation significantly reduced NADPH oxidase activity in penile tissue. Based on the results of the study, resveratrol may be a treatment target under conditions in which NADPH oxidase activity is increased in penile tissue. In line with the results of this study, the effect of resistin on CC must be investigated at different concentrations and incubation times.
\end{abstract}

Keywords: Resveratrol, Resistin, Erectile dysfunction, Corpus cavernosum, Rabbit

Öz

Amaç: Resistin, obezite ile indüklenen insülin direnci ve endotelyal disfonksiyon aracılı kardiyovasküler sistem hastalıklarının patogenezinde önemli bir faktör olarak bilinmektedir. Endotel disfonksiyonu, erektil disfonksiyonun en önemli nedenlerinden biridir. Polifenol resveratrol, endotel disfonksiyonu önlemek, redoks regülasyonu ve nitrik oksit üretimini sağlayarak endotel bağımlı vasküler gevşemeyi indüklemek gibi çeşitli farmakolojik fonksiyonlara sahiptir. Bu çalışma ile, resistin ile bozulan endotel aracılı yanıtları resveratrol düzeltir, hipotezi test edilmiştir.

Correspondence: Nergiz Durmuş MD, Dokuz Eylül University Faculty of Medicine, Department of Pharmacology, İzmir, Turkiye E-mail: nergiz.durmus@deu.edu.tr ORCID-ID: orcid.org/0000-0003-3733-4445

Received: 04.02.2020 Accepted: 10.03 .2020

Cite this article as: Güngör T, Acar S, Kahraman E, Bozkurt O, Durmuş N. Role of Resveratrol on the Effect of Resistin in Rabbit Corpus Cavernosum. J Urol Surg 2020;7(3):204-210.

๑Copyright 2020 by the Association of Urological Surgery / Journal of Urological Surgery published by Galenos Publishing House. 
Gereç ve Yöntem: Dokuların resistin ile 24 saatlik inkübasyon periyodunun ardından, tavşan korpus kavernosumunda (KK), resveratrol varlığında ve yokluğunda, endotel bağımlı ve bağımsız gevşeme yanıtları, nikotin amid adenin dinükleotid fosfat (NADPH) oksidaz seviyesi değerlendirildi.

Bulgular: Resistin, endotel-bağımlı ve bağımsız gevşeme yanıtlarını bozmadı. Resistin varlığında, NADPH oksidaz seviyeleri CC dokularında \%28 arttı, ancak fark istatistiksel olarak anlamlı değildi. Resveratrol varlığında resistin uygulanan gruptaki NADPH oksidaz aktivitesinde, tek başına resistin grubuna oranla, anlamlı derecede azalma oldu.

Sonuç: Resistin, KK'de fonksiyonel yanıtlar ve NADPH oksidaz aktivitesinde herhangi bir değişikliğe neden olmadı, ancak resveratrol inkübasyonu penil dokudaki NADPH oksidaz aktivitesini anlamlı olarak azalttı. Çalışmanın sonuçlarına dayanarak, resveratrolün, penil dokuda NADPH oksidaz aktivitesinin arttığı koşullarda bir tedavi hedefi olabileceği düşünülmektedir. Bu çalışmanın sonuçları doğrultusunda, resistinin KK üzerindeki etkisinin farklı konsantrasyonlarda ve farklı inkübasyon sürelerinde araştırılması gereklidir.

Anahtar Kelimeler: Resveratrol, Resistin, Erektil disfonksiyon, Korpus kavernosum, Tavşan

\section{Introduction}

Resistin, a hormone released from adipose tissue, is associated with increased endothelial dysfunction in types 1 and 2 diabetes, coronary artery disease, and atherogenic dyslipidemia (1). In clinical and experimental studies, increased resistin level was also associated with obesity (2). In vitro experimental studies, in which resistin concentration was equivalent to high resistin concentration in humans, showed disrupted endotheliumdependent relaxation responses in vessels, resulting in endothelial dysfunction $(3,4)$. Resistin causes endothelial dysfunction by increasing the reactive oxygen species and decreasing nitric oxide (NO) activities (4), promoting the synthesis of endothelin-1 (ET-1) a vasoconstrictor substance (5). Risk factors, such as hyperlipidemia, obesity, smoking, and high blood pressure, cause endothelial dysfunction-mediated erectile dysfunction (ED) (6). The relationship of resistin and ED has not been demonstrated. One clinical study reported an increase in blood resistin levels in patients with ED accompanying type 2 diabetes (7).

Resveratrol as an antioxidant flavonoid has highly targeted molecular effects on the endothelium. Resveratrol increases endothelial NO production through upregulation of endothelial nitric oxide synthase (eNOS) expression, enhancement of eNOS activity, and prevention of eNOS uncoupling (8). Resveratrol prevents vascular and penile endothelial functions in hypercholesterolemic rabbits (9). In addition to its effect on the endothelium, resveratrol reduces elevated resistin levels due to obesity (10). The present study was designed to answer the following questions:

1. Does resistin impair in vitro functional responses in rabbit corpus cavernosum (CC) tissue?

2. If so, does resveratrol restore this effect?

\section{Material and Methods}

\section{Animals, Tissue Preparation, and Study Protocols}

This study was approved by the Animal Care and Investigational Committee (22/2016) in accordance with the "Guide for the
Care and Use of Laboratory Animals" published by the United States NIH. Adult New Zealand male rabbits weighing 2-3 kg were housed individual in identical cages in an air-conditioned room under a $12 \mathrm{~h}$ light-dark cycle. The animals were sacrificed with $60 \mathrm{mg} / \mathrm{kg}$ thiopental. The penis was rapidly removed and placed in a cold $\left(+4^{\circ} \mathrm{C}\right)$ Krebs solution composed of the following (mM): $136.9 \mathrm{NaCl}, 2.7 \mathrm{KCl}, 0.5 \mathrm{KH}_{2} \mathrm{PO}_{4^{\prime}}, 1.8 \mathrm{CaCl}_{2^{\prime}} 0.6 \mathrm{MgSO}_{4^{\prime}} 11.9$ $\mathrm{NaHCO}_{3^{\prime}}$ and 11.5 glucose; $\mathrm{pH}: 7.4$. After removal of the tunica albuginea and corpus spongiosum tissue, the $\mathrm{CC}$ was divided into two pieces longitudinally. Two or three cavernosal strips of approximately equal size $\left(3 \times 3 \times 4 \mathrm{~mm}^{3}\right)$ were obtained from each part of the cavernosum. The incubation protocol included three different conditions: a) incubation of CC tissues in Krebs solution with for $24 \mathrm{~h}$ at $4^{\circ} \mathrm{C}$ as the control group, b) incubation of CC tissues in Krebs solution containing $40 \mathrm{ng} / \mathrm{mL}$ resistin for $24 \mathrm{~h}$ at $4^{\circ} \mathrm{C}$ as the resistin group, and c) incubation in Krebs solution containing $40 \mathrm{ng} / \mathrm{mL}$ resistin for $24 \mathrm{~h}$ and added with $30 \mu \mathrm{M}$ resveratrol in the last $2 \mathrm{~h}$ of incubation period at $4^{\circ} \mathrm{C}$ as resistin + resveratrol group. The in vitro treatment conditions for resistin and resveratrol were based on previously published doses $(4,11)$.

\section{In Vitro Organ Bath Studies}

After $24 \mathrm{~h}$ of incubation period, the CC strips were suspended between two stainless steel hooks in organ baths containing 10 $\mathrm{mL}$ Krebs solution. The solution was kept at $37^{\circ} \mathrm{C}$ and gassed continuously with a $95 \% \mathrm{O}_{2}$ and $5 \% \mathrm{CO}_{2}$ gas mixture at $\mathrm{pH}$ 7.35. The CC was mounted under $1 \mathrm{~g}$ tension. The tissues were washed with Krebs solution every 15 min for 90 min. After an equilibrium period at resting tension, we conducted a viability protocol as follows. CC tissues were contracted with $120 \mathrm{mM}$ potassium chloride $(\mathrm{KCl})$ at the beginning and end of the study protocol. The tissues whose end $\mathrm{KCl}$ contraction response decreased by more than 10\% compared with the initial $\mathrm{KCl}$ contraction response were excluded. $\mathrm{KCl}$-induced contraction responses obtained after $24 \mathrm{~h}$ of incubation period were also compared with obtained from tissues immediately contracted with $\mathrm{KCl}$ after sacrifice to evaluate the effect of incubation condition on the tissue viability. 
Following the viability protocol, CC tissues were contracted to $\sim 80 \%$ of their maximal contractions via the addition of 30 $\mathrm{mM}$ phenylephrine (Phe). Then, relaxation dose-response curves were constructed by the addition of cumulative concentrations of acetylcholine (Ach) $\left(10^{-8}-10^{-5} \mathrm{M}\right)$ and sodium nitroprusside (SNP) $\left(10^{-9}-10^{-6} \mathrm{M}\right)$ to evaluate the endothelium-dependent and -independent relaxation. Dose-response curves were obtained with cumulative doses of ET-1 $\left(10^{-11}-10^{-7} \mathrm{M}\right)$ to evaluate the endothelium-dependent contraction responses. Isometric tensions were recorded with an amplifier system (MP30 BIOPAC Systems, Santa Barbara, CA, USA) on a computer by using the BIOPAC computer program.

\section{Measurement of NADP+ / NADPH Concentration}

Following the incubation period, the tissues were frozen in liquid nitrogen and were used in the working day. NADP+ / NADPH Assay Kit (Abnova, KA1663) was used to determine NADP+ / NADPH concentration in cavernosal samples. Briefly, the concentration of NADP+ / NADPH was determined following the manufacturer's protocol.

\section{Chemicals}

The chemicals used in this study were as follows: resveratrol (Biovision), dimethyl sulfoxide (DMSO; Merck), ET-1; diphenyliodonium chloride; Ach; SNP; Phe (Sigma-Aldrich); recombinant human resistin (ab73252) (Abcam), Phe, Ach, ET-1, and SNP stock solutions prepared in distilled water. Resveratrol stock solution was prepared with $0.01 \%$ DMSO. The drugs were prepared as stock solutions and diluted on the working day.

\section{Statistical Analysis}

Relaxation responses to Ach and SNP were calculated based on the percentage of Phe contraction. Contraction responses to ET-1 were calculated based on the percentage of $\mathrm{KCl}$ contraction. The sensitivity to agonists was assessed by potency $(\mathrm{pD} 2)=-\log E \mathrm{C} 50(\mathrm{M})$. Data were expressed as mean \pm standard error of the mean. Statistical analysis was performed by oneway analysis of variance, post-hoc Tukey's test in the case of three groups, and Student's t-test in the case of two groups (GraphPad, San Diego, CA, USA). P-values $<0.05$ were considered statistically significant.

\section{Results}

\section{Evaluation of Functional Responses of CC Tissue in In Vitro Organ Bath}

To evaluate the effect of $24 \mathrm{~h}$ incubation period on tissue viability we applied $120 \mathrm{mM} \mathrm{KCl}$ to $\mathrm{CC}$ tissues which were suspended in organ bath on the same day $(n=8)$ and $24 \mathrm{~h}$ after sacrifice $(\mathrm{n}=8)$. When we compared the $\mathrm{KCl}$-induced contractions of both groups, no statistically significant difference was observed between them (0 h, 1354 mg; 24 h, $2180.5 \mathrm{mg}$ ) ( $p>0.05)$.

To evaluate tissue viability on the study day, we applied $120 \mathrm{mM}$ $\mathrm{KCl}$ to $\mathrm{CC}$ tissues at the beginning and end of the organ bath experimental protocol. The mean of $\mathrm{KCl}$-induced contractile responses of three groups obtained at the beginning of the study protocol $(1572.25 \mathrm{mg})$ were not statistically different from those obtained at the end of the study protocol (1727.46 $m g)(p>0.05)$.

\section{Evaluation of Ach-mediated Relaxation Responses}

The dose-response curves of Ach were obtained using CC tissue to evaluate the effect of resistin on endothelium-dependent relaxation in the absence and presence of resveratrol. In the control group, Ach $\left(10^{-8}-10^{-5} \mathrm{M}\right)$ elicited a concentrationdependent relaxation with a maximal relaxation (Emax) value of $79.03 \% \pm 8.18 \%$ and $a \mathrm{pD}_{2}$ value of $6.24 \pm 0.23$. In the resistin group, Ach caused relaxation with an Emax value of $82.83 \% \pm 10.91 \%$ and a pD2 value of $6.39 \pm 0.32$. Ach caused relaxation with an Emax value of $68.71 \% \pm 11.81 \%$ and a pD2 value of $6.17 \pm 0.49$ in the resistin and resveratrol group. No

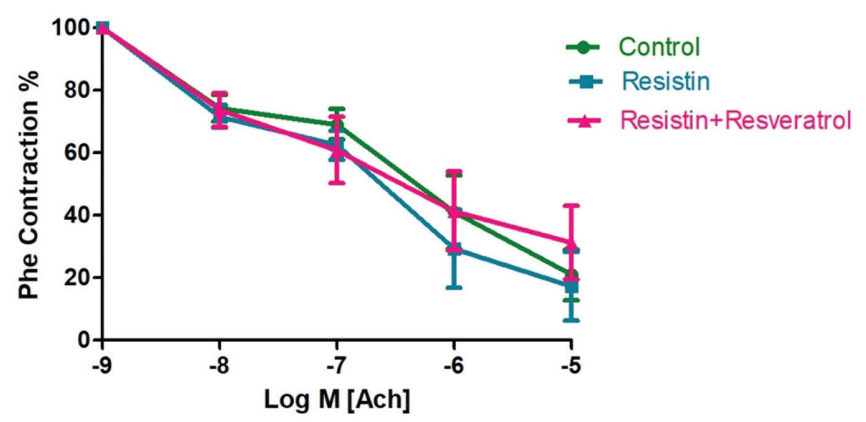

Figure 1. Ach-mediated relaxation responses: control, resistin, and resistin + resveratrol group (each group included $n=8$ strips). One-Way ANOVA and post-hoc Tukey's test were used. $p<0.05$ was considered significant

Table 1. Emax and contraction responses and pD2 of the agonists in rabbit corpus cavernosum tissues

\begin{tabular}{|l|l|l|l|l|l|l|}
\hline & \multicolumn{2}{|l|}{ Acetylcholine } & \multicolumn{2}{l|}{ Endothelin-1 } & \multicolumn{2}{l|}{ Sodium nitroprusside } \\
\cline { 2 - 7 } & Emax $\%$ & $\mathbf{p D}_{2}$ & Emax $\%$ & $\mathbf{p D}_{2}$ & Emax $\%$ & $\mathbf{p D}_{2}$ \\
\hline Control grup & $79.03 \pm 8.2$ & $6.24 \pm 0.2$ & $99.54 \pm 15.7$ & $8.01 \pm 0.4$ & $161.3 \pm 13.2$ & $8.37 \pm 0.4$ \\
\hline Resistin group & $82.83 \pm 10.9$ & $6.17 \pm 0.5$ & $77.8 \pm 5.5$ & $7.48 \pm 0.1$ & $146.2 \pm 16.9$ & $8.63 \pm 0.4$ \\
\hline Resistin + resveratrol group & $68.71 \pm 11.8$ & $6.17 \pm 0.5$ & $77.58 \pm 11.3$ & $7.41 \pm 0.2$ & $150.8 \pm 13.2$ & $8.58 \pm 0.5$ \\
\hline Control, resistin and resistin + resveratrol groups (each group included $n=7$ strips), One-Way ANOVA post-hoc Tukey test was used, $p<0.05$ was considered significant \\
\hline
\end{tabular}




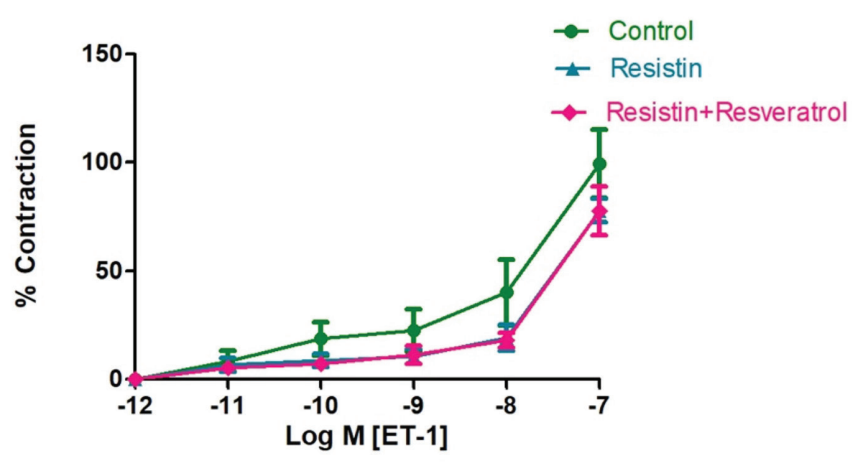

Figure 2. Endothelin-1-mediated contractile responses: control, resistin, and resistin + resveratrol group (each group included $n=8$ strips). One-Way ANOVA and post-hoc Tukey's test were used. $p<0.05$ was considered significant

significant difference was observed between the groups. Resistin alone and the presence of resveratrol did not augment the efficacy and pD2 of Ach ( $>0.05)$ (Figure 1).

\section{Evaluation of ET-1-mediated Contraction Responses}

In the control, resistin, and resistin + resveratrol groups, ET-1 caused dose-dependent contraction responses. Maximum contraction responses obtained with ET-1 were $99.54 \% \pm 15.67 \%$; $77.8 \% \pm 5.53 \% ; 77.58 \% \pm{ }^{11.26 \%}$. No significant difference was noted in the Emax values of the groups ( $p>0.05$ ) (Figure 2). When $\mathrm{pD} 2$ values were compared, no significant difference was observed between three groups $(8.01 \pm 0.35,7.48 \pm 0.12$, and $7.41 \pm 0.16)(p>0.05)$.

\section{Evaluation of SNP-mediated Relaxation Responses}

Cumulative doses of SNP $\left(10^{-9}-10^{-6} \mathrm{M}\right)$ were administrated to the organ bath to evaluate endothelium-independent relaxation. SNP elicited a concentration-dependent relaxation with Emax values of $161.3 \% \pm 13.17 \%$ in the control group, $146.2 \% \pm 16.85 \%$ in the resistin group and $150.8 \% \pm 13.15 \%$ in the resistin + resveratrol group (Figure 3 ). $\mathrm{pD}_{2}$ values were $8.37 \pm 0.42,8.63 \pm 0.37$, and $8.58 \pm 0.45$ in control, resistin, and resistin + resveratrol groups, respectively. No significant difference was observed between the groups for both Emax and $\mathrm{pD}_{2}$ values $(\mathrm{p}>0.05)$.

\section{Evaluation of NADP + / NADPH Measurement in CC Tissues}

The NADP+ / NADPH ratio increased by $28 \%$ in the resistin group, although no statistical difference was observed. However, resveratrol incubation caused a significant decrease in NADP+ I NADPH ratio compared with the resistin group $(p<0.05)$ (Figure 4$)$.

\section{Discussion}

In the present study, resistin did not impair endotheliumdependent and -independent relaxation responses. In the

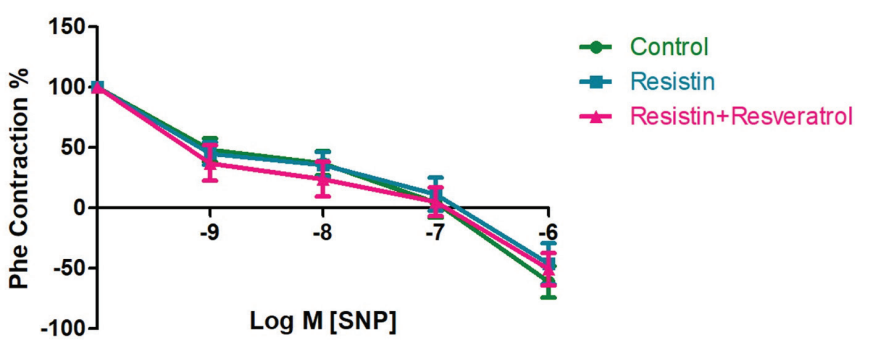

Figure 3. Sodium nitroprusside-mediated relaxation responses: control, resistin, and resistin + resveratrol group (each group included $n=8$ strips). One-Way ANOVA and post-hoc Tukey's test were used. $p<0.05$ was considered significant

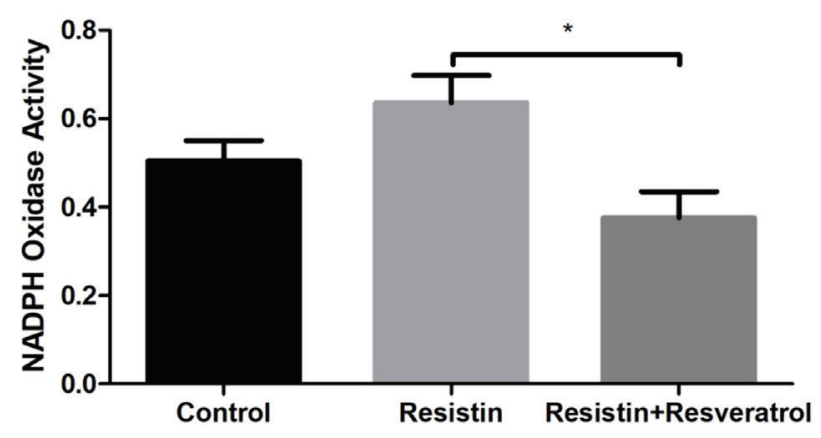

Figure 4. NADP+ / NADPH measurement: control, resistin, and resistin + resveratrol groups (each group included $n=7$ strips). One-Way ANOVA and post-hoc Tukey's test were used. $p<0.05$ was considered significant

NADP: Nicotinamide adenine dinucleotide phosphate

presence of resistin, NADPH oxidase levels increased in the CC tissue. However, the difference was not statistically significant. Resveratrol administration caused a significant decrease in NADPH oxidase activity in the resistin-treated group compared with the resistin-alone group.

The integrity of endothelium in cavernous tissue is important for erection physiology. Endothelium-released NO has a major role among many mediators in the erection. NO activates a cyclic guanosine monophosphate (cGMP)-dependent cellular mechanism in the smooth muscle cell and causes relaxation of smooth muscles. eNOS, which is involved in the synthesis of endothelium-derived NO in penile tissue, is activated in two ways. The initial phase of erection occurs via binding of Ach to the muscarinic receptor, which leads to $\mathrm{Ca} /$ calmodulin-induced activation of the eNOS and NO synthesis. NO-dependent relaxation in cavernous smooth muscle induces blood flow shear forces that cause eNOS phosphorylation and activity of the enzyme at resting Ca level. Endothelial dysfunction is one of the leading causes of ED. Chronic diseases causing endothelial dysfunction, such as atherosclerosis, diabetes, and metabolic syndrome, are accompanied by a high rate of ED. Impaired NO bioactivity has also been supported by various animal models of hypertension, diabetes, and hypercholesterolemia-induced ED (12). 
Resistin is an adipokine that plays a role in the development of insulin resistance and obesity (13). High circulating resistin levels ( $>40 \mathrm{ng} / \mathrm{mL}$ ) are related to types 1 and 2 diabetes (14). Resistin has also been found in atherosclerotic tissues (15). Studies linking resistin with vascular dysfunction have investigated the effect of resistin on endothelium-released relaxing factors, such as insulin, bradykinin, and Ach $(3,4,16,17)$. To our knowledge, no study has investigated the in vitro effect of resistin on penile tissue. Thus, in the present study, we aimed to investigate the cellular effects of resistin and its derivatives on functional responses of CC. After $24 \mathrm{~h}$ of incubation with $40 \mathrm{ng} / \mathrm{mL}$ resistin, endothelium-dependent relaxation and contraction responses were assessed by Ach and ET-1 dose-response curves, respectively. Relaxation dose-response curves of SNP were obtained to evaluate the endothelium-independent relaxation. We also investigated the effect of resistin on endotheliumdependent and independent responses of CC in the presence of resveratrol.

In the present study, $24 \mathrm{~h}$ of incubation of penile tissues with resistin caused no change in Emax response and $\mathrm{pD}_{2}$ of Ach. Several studies evaluated the effects of resistin on coronary arteries of different species. One research reported that $10 \mathrm{~min}$ incubation with low- and high-dose resistin (10 or $40 \mathrm{ng} / \mathrm{mL}$ ) did not alter Ach-induced relaxation responses but decreased bradykinin responses without disrupting NO or prostacyclin signaling in dog coronary artery (16). Another study on porcine coronary artery reported a decrease in bradykinin-mediated relaxation responses and an increase in superoxide $\left(\mathrm{O}_{2}^{-}\right)$anions with $24 \mathrm{~h}$ resistin incubation ( $40 \mathrm{ng} / \mathrm{mL}$ ) (4). According to the results of these studies, resistin impairs bradykinin-mediated relaxation responses but not Ach in the coronary artery, which is independent of incubation period and dose. However, the in vitro effect of resistin on Ach-mediated relaxation was observed in the mouse aorta. Seto et al. demonstrated decreased Achmediated relaxation responses in healthy and diabetic mouse aorta after $30 \mathrm{~min}$ incubation with $40 \mathrm{ng} / \mathrm{mL}$ resistin (3). On the other hand, Lou and colleagues showed that $1 \mathrm{~h}$ incubation with $100 \mathrm{ng} / \mathrm{mL}$ resistin did not alter Ach-mediated NO responses in mouse aorta but changed insulin-dependent $\mathrm{NO}$ responses and reduced eNOS phosphorylation via increasing NADPH oxidase activity and free oxygen radicals (18). In the present study, we observed an increase in NADPH oxidase activity after a $24 \mathrm{~h}$ incubation at $40 \mathrm{ng} / \mathrm{ml}$ dose, but the difference did not reach statistical significance. According to the literature, resistin responses on endothelium can vary depending on the species of animal, vessel, incubation period, and dose. As the major limitation of our study, regardless of the absence of any effect, the ineffectiveness of resistin cannot be proven given that we have not tested its effect on a different substance that produces endothelial-mediated relaxation at various times and doses.
Resistin's interaction with ET-1, a vasoconstrictor substance, contributes to its effect on vascular tone. In a clinical study, resistin and ET-1 levels correlated with each other in blood samples collected from 76 metabolic syndrome patients (19). In an in vivo study, infusion of $30 \mathrm{mg} / \mathrm{h} / \mathrm{kg}$ resistin potentiated ET1 -induced enhancement in blood pressure in rats (20). In vitro cell culture studies have reported that after a $24 \mathrm{~h}$ incubation period, resistin increased ET-1 secretion in endothelial cells (5) but caused no effect on its expression (21). In the present study, based on the finding that resistin exposure to endothelial cells for $24 \mathrm{~h}$ leads to an enhancement in ET-1 release, we investigated whether resistin causes alteration in the functional responses of ET-1 in CC. Although in vivo studies have shown that resistin potentiates the vasoconstriction response of ET-1, to our knowledge, no study investigated the effect of resistin on functional responses of ET-1 in vitro. In the present study, ET-1, which was cumulatively tested in CC, produced negligible contraction response in the first doses, whereas the contraction response was observed at $10^{-7} \mathrm{M}$. Similar dose-response curves were obtained in the presence of resistin without observing changes in the Emax response.

SNP, a NO donor, causes endothelium-independent relaxation response via the cGMP pathway in smooth muscles (22). Several clinical studies stated that a correlation exists between circulating resistin levels and endothelium-independent relaxation responses-induced by SNP (23), although others reported otherwise (24). Kougias et al. (4) reported that resistin caused a significant reduction (11\%) in the relaxation response of porcine coronary artery-induced by a single dose of SNP $\left(10^{-6}\right.$ M). In the present study, the Emax response obtained with the cumulative $\left(10^{-9}-10^{-6} \mathrm{M}\right)$ addition of SNP was $161 \%$ and reduced to $146 \%$ in resistin-treated penile tissues. Resistin caused a $12.4 \%$ reduction in the SNP Emax response. Although the dose and incubation periods were the same as those in the work of Kougias et al. (4), the difference between Emax responses was not statistically significant. This result may be due to tissue difference.

Resveratrol, which is commonly consumed as a plant in the Mediterranean diet, is associated with a reduced risk of cardiovascular disease (25). Vascular dysfunction is the first step in the emergence of many disease states in the cardiovascular system, and oxidative stress is a key mechanism in the pathogenesis of vascular dysfunction (26). Oxidative stress results from the generation of reactive oxygen species, which is considered as a critical factor in the development of NO bioavailability and ED (26). NADPH oxidase is a key source of $\mathrm{O}_{2}^{-}$in the penile tissue (27). In a recent study of our laboratory, the protective effect of resveratrol on ED was shown in hypercholesterolemic rabbit CC (9). Following this study, resveratrol was shown to improve vascular dysfunction in 
addition to its protective effect. These effects reduced NADPH oxidase activity and increased the phosphorylation of the domain responsible for the activation of eNOS (28).

\section{Study Limitations}

In the present study, resveratrol significantly reduced NADPH oxidase activity in the penile tissues incubated with resistin. However, our findings reveal that although an increase in NADPH oxidase activity was recorded in the resistin-treated group, the finding was not statistically significant. Therefore, we could not confirm that resveratrol reduces the resistin-mediated increase in NADPH oxidase activity. The reduction caused by resveratrol may be due to the NADPH oxidase binding capability. Given the lack of a group incubated with resveratrol only, its direct efficacy on NADPH oxidase activity could not be evaluated, thus limiting our study.

\section{Conclusion}

Our findings suggest that the effect of resistin on endotheliumdependent responses and NADPH oxidase activity at different doses and incubation should be confirmed in the penile tissue. The effects of resistin differ depending on the species, and further studies are needed to investigate the relationship between erectile pathophysiology and resistin in human penile tissue. Given the results of this study and those of previous studies conducted in our laboratory, resveratrol may be an alternative treatment target for ED and may serve as guide for future studies.

\section{Ethics}

Ethics Committee Approval: This study was approved by the Animal Care and Investigational Committee (22/2016) in accordance with the "Guide for the Care and Use of Laboratory Animals" published by the United States NIH.

Informed Consent: Patient consent is not required.

Peer-review: Externally peer-reviewed.

\section{Authorship Contributions}

Concept: T.G., S.A., N.D., Design: T.G., S.A., N.D., Data Collection or Processing: T.G., S.A., N.D., Analysis or Interpretation: O.B., Literature Search: T.G., Writing: T.G., N.D.

Conflict of Interest: No conflict of interest was declared by the authors.

Financial Disclosure: This study was supported by Research Foundation of Dokuz Eylül University (grant number: 2018KB. SAG066).

\section{References}

1. Geyikli İ, Keskin M, Kör Y, Akan M. Increased resistin serum concentrations in patients with type 1 diabetes mellitus. J Clin Res Pediatr Endocrinol 2013;5:189-193.

2. Degawa-Yamauchi M, Bovenkerk JE, Juliar BE, Watson W, Kerr K, Jones R, Zhu 0, Considine RV. Serum resistin (FIZZ3) protein is increased in obese humans. J Clin Endocrinol Metab 2003;88:5452-5455.

3. Seto SW, Lam TY, Or PM, Lee WY, Au AL, Poon CC, Li RW, Chan SW, Yeung JHK, Leung GPH, Lee SMY, Ngai SM, Kwan YW. Folic acid consumption reduces resistin level and restores blunted acetylcholine-induced aortic relaxation in obese/diabetic mice. J Nutr Biochem 2010;21:872-880.

4. Kougias $\mathrm{P}$, Chai $\mathrm{H}$, Lin PH, Lumsden AB, Yao Q, Chen C. Adipocyte-derived cytokine resistin causes endothelial dysfunction of porcine coronary arteries. J Vasc Surg 2005;41:691-698.

5. Verma S, Li SH, Wang CH, Fedak PW, Li RK, Weisel RD, Mickle DAG. Resistin promotes endothelial cell activation: further evidence of adipokineendothelial interaction. Circulation 2003;108:736-740.

6. DeLay KJ, Haney N, Hellstrom WJ. Modifying risk factors in the management of erectile dysfunction: A review. World J Mens Health 2016;34:89-100.

7. Derosa G, Romano D, Tinelli C, D'Angelo A, Maffioli P. Prevalence and associations of erectile dysfunction in a sample of Italian males with type 2 diabetes. Diabetes Res Clin Pract 2015;108:329-323.

8. Li H, Xia N, Hasselwander S, Daiber A. Resveratrol and vascular function. Int J Mol Sci 2019;20:2155.

9. Soner BC, Murat N, Demir O, Guven H, Esen A, Gidener S. Evaluation of vascular smooth muscle and corpus cavernosum on hypercholesterolemia. Is resveratrol promising on erectile dysfunction? Int J Impot Res 2010;22:227233.

10. Mercader J, Palou A, Bonet ML. Resveratrol enhances fatty acid oxidation capacity and reduces resistin and Retinol-Binding Protein 4 expression in white adipocytes. J Nutr Biochem 2011;22:828-834.

11. Boydens C, Pauwels B, Vanden L, Van J. Protective effect of resveratrol and quercetin on in vitro-induced diabetic mouse corpus cavernosum. Cardiovasc Diabetol 2016;15:46.

12. Burnett $A L$. The role of nitric oxide in erectile dysfunction: implications for medical therapy. J Clin Hypertens (Greenwich) 2006;8(12 Suppl 4):53-62.

13. Lazar MA. Resistin- and obesity-associated metabolic diseases. Horm Metab Res 2007;39:710-716.

14. Fehmann $\mathrm{HC}$, Heyn J. Plasma resistin levels in patients with type 1 and type 2 diabetes mellitus and in healthy controls. Horm Metab Res 2002;34:671673

15. Burnett MS, Lee CW, Kinnaird TD, Stabile E, Durrani S, Dullum MK, et al. The potential role of resistin in atherogenesis. Atherosclerosis 2005;182:241248.

16. Dick GM, Katz PS, Farias M 3rd, Morris M, James J, Knudson JD, Tune JD. Resistin impairs endothelium-dependent dilation to bradykinin, but not acetylcholine, in the coronary circulation. Am J Physiol Heart Circ Physiol 2006;291:2997-3002.

17. Gentile MT, Vecchione C, Marino G, Aretini A, Di Pardo A, Antenucci G, et al. Resistin impairs insulin-evoked vasodilation. Diabetes 2008;57:577-583.

18. Luo J, Huang L, Wang A, Liu Y, Cai R, Li W, Zhou MS. Resistin-induced endoplasmic reticulum stress contributes to the impairment of insulin signaling in endothelium. Front Pharmacol 2018;9:1226.

19. Samsamshariat SZA, Sakhaei F, Salehizadeh L, Keshvari M, Asgary S. Relationship between resistin, endothelin-1, and flow-mediated dilation in patient with and without metabolic syndrome. Adv Biomed Res 2019;8:16.

20. Chuang TY, Au LC, Wang LC, Ho LT, Yang DM, Juan CC. Potential effect of resistin on the ET-1-increased reactions of blood pressure in rats and $\mathrm{Ca} 2+$ 
signaling in vascular smooth muscle cells. Journal of Cellular Physiology 2012;227:1610-1618.

21. Takahashi K, Totsune K, Kikuchi K, Murakami 0. Expression of endothelin-1 and adrenomedullin was not altered by leptin or resistin in bovine brain microvascular endothelial cells. Hypertension Research 2006;29:443-448.

22. Fu $Q$, Yao DH, Jiang YQ. Effect of sodium nitroprusside on hemodynamics of corpus cavernosum in Chinese. Asian J Androl 2001;3:311-313.

23. Shetty GK, Economides PA, Horton ES, Mantzoros CS, Veves A. Circulating adiponectin and resistin levels in relation to metabolic factors, inflammatory markers, and vascular reactivity in diabetic patients and subjects at risk for diabetes. Diabetes Care 2004;27:2450-2457.

24. Bahia L, Aguiar LG, Villela N, Bottino D, Godoy-Matos AF, Geloneze B, Tambascia M, Bouskela E. Relationship between adipokines, inflammation, andvascular reactivity in lean controls and obese subjects with metabolic syndrome. Clinics (Sao Paulo) 2006;61:433-440.

25. Simopoulos AP. The Mediterranean diets: What is so special about the diet of Greece? The scientific evidence. J Nutr 2001:131:3065-3073.

26. Shah AM, Channon KM. Free radicals and redox signalling in cardiovascular disease. Heart 2004;90:486-487.

27. Jin L, Burnett AL. NADPH oxidase: recent evidence for its role in erectile dysfunction. Asian J Androl 2008;10:6-13.

28. Murat N, Korhan P, Kizer O, Evcim S, Kefi A, Demir Ö, Gidener S, Atabey $\mathrm{N}$, Esen AA. Resveratrol Protects and Restores Endothelium-Dependent Relaxation in Hypercholesterolemic Rabbit Corpus Cavernosum. J Sex Med 2016;13:12-21. 